\title{
Source of lead in Central American and Caribbean mineralization, II. Lead isotope provinces
}

\author{
George L. Cumming \\ Institute of Earth and Planetary Physics and Department of Physics, University of Alberta. Edmonton. Alta. T6G 2JI (Canada) \\ Stephen E. Kesler \\ Department of Geological Sciences. University of Michigan, Ann Arbor, MI 48109 (U.S.A.)
}

and

\section{Dragan Krstic}

Department of Physics, University of Alberta, Edmonton, Alta. T6G $2 J 1$ (Cunada)

Received March 13, 1981

Revised version received July 7,1981

\begin{abstract}
In an earlier study of Mesozoic and Cenozoic mineralization in Central America and the Caribbean region, we found that lead isotopic compositions of deposits in northern Central America, which is underlain by a pre-Mesozoic craton, ranged to higher ${ }^{206} \mathrm{~Pb} /{ }^{204} \mathrm{~Pb}$ and ${ }^{207} \mathrm{~Pb} /{ }^{204} \mathrm{~Pb}$ compositions than did deposits from elsewhere in the region, where the basement is Mesozoic oceanic material. Using 16 analyses for 12 new deposits, as well as new analyses for 11 of the samples studied previously, we have found that lead isotopic compositions correlate closely with crustal type but show little or no correlation with depth to the M-discontinuity. The deposits are divisible into three main groups including (in order of increasing ${ }^{207} \mathrm{~Pb} /{ }^{204} \mathrm{~Pb}$ and ${ }^{208} \mathrm{~Pb} /{ }^{204} \mathrm{~Pb}$ ratio): (1) deposits in southern Central America and all deposits in the Greater Antilles except Cuba; (2) all deposits in northern Central America; and (3) the Cuban deposits. Southern Central American and Caribbean lead is higher in ${ }^{207} \mathrm{~Pb} /{ }^{204} \mathrm{~Pb}$ and ${ }^{208} \mathrm{~Pb} /{ }^{204} \mathrm{~Pb}$ than most mid-ocean ridge basalts but could have been derived directly or indirectly from undepleted mantle. Northern Central America can be divided into the Maya block, which belongs to the Americas plate, and the Chortis block, which belongs to the Caribbean plate. Maya block deposits fall along a linear array whereas those of the Chortis block (except the Monte Cristo deposit) form a cluster. These results suggest that the Maya block is underlain by crust or mantle with a large range of $\mathrm{U} / \mathrm{Pb}$ and $\mathrm{Th} / \mathrm{U}$ ratios, whereas the Chortis block basement is more homogeneous. Two-stage model calculations indicate an age of about $2280 \pm 310 \mathrm{~m}$.y. for the Maya block basement, although no such rocks are known in the region. Comparison of the Chortis block data to our recently published lead isotopic analyses of Mexican deposits shows considerable similarities suggesting that the Chortis block could have been derived from Mexico.
\end{abstract}

\section{Introduction}

In an earlier study of Mesozoic and Cenozoic mineralization in Central America and the Caribbean region [1] we noted that although most deposits exhibited generally similar lead isotope compositions approximately linearly related, it was possible to recognize smaller groupings of deposits with close similarities in both lead isotopic composition and geologic environment. In particular, we found that the lead isotopic compositions of deposits from northern Central America, which is underlain by a pre-Mesozoic craton (Fig. 1), ranged to higher ratios than did deposits from elsewhere 


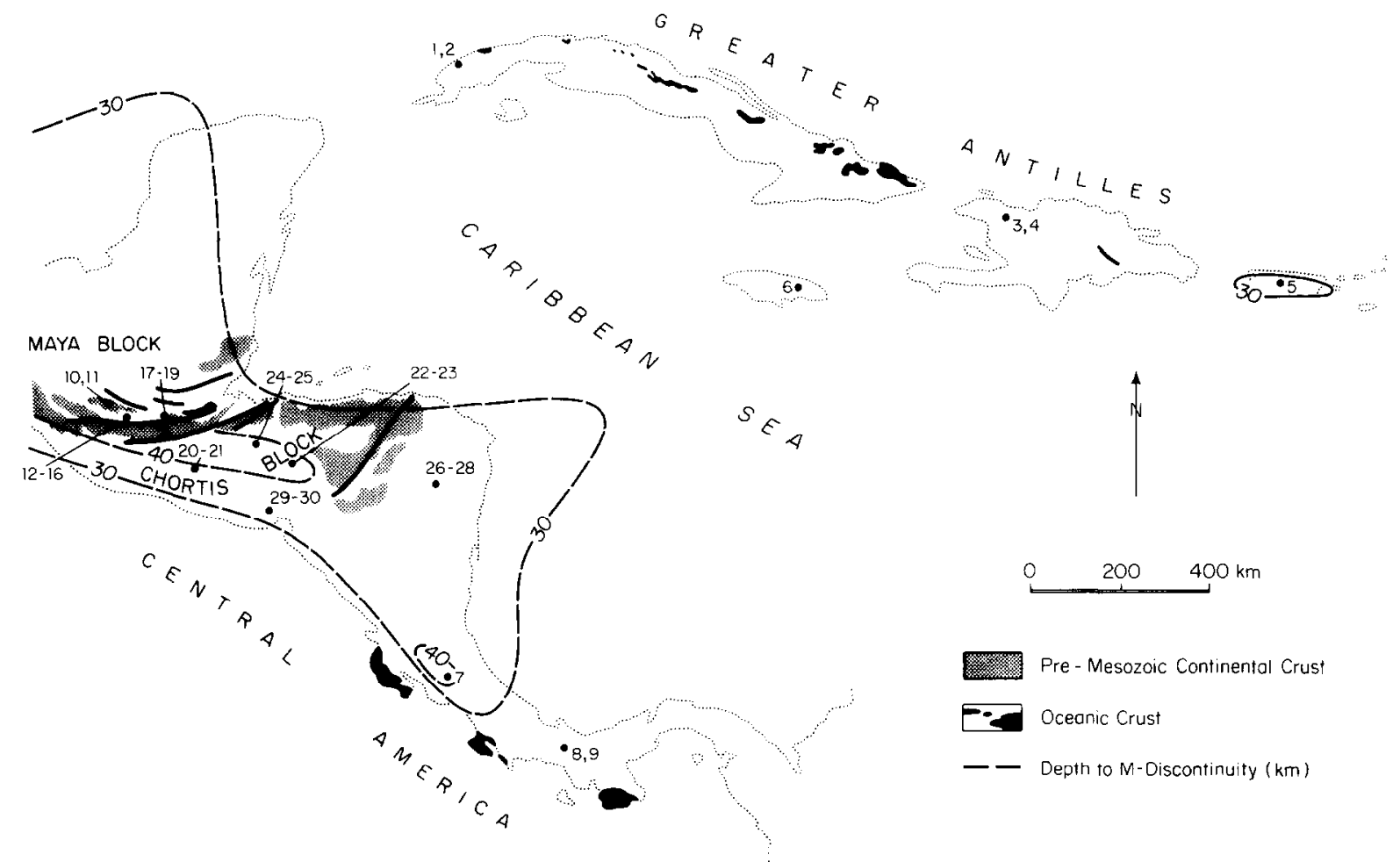

Fig. 1. Map of Central America and the Caribbean region showing distribution of pre-Mesozoic continental crust as well as oceanic crust, largely of Mesozoic age. Depth to M-discontinuity is also shown, after Case [20]. Locations of analyzed deposits are indicated by numbers that correspond to numbers in Tables 1 and 2 .

in the region, where the basement is Mesozoic oceanic material. In a recent summary of such work, Doe and Zartman [2] have shown that there is indeed a close relation between the type of basement rocks underlying an area and the isotopic characteristics of lead in ore deposits of the area. Stacey et al. [3], Zartman [4] and Stacey and Zartman [5] have used the lead isotopic composition of Mesozoic and Cenozoic mineral deposits to characterize and date Precambrian and younger rocks concealed beneath the deposits. In order to evaluate more completely the relation between crustal environment and the lead isotopic composition of the widespread Mesozoic and Cenozoic ore deposits of the Caribbean region, we have obtained 16 new lead isotopic analyses from twelve previously unstudied deposits and district (Table 1 and 2; Fig. 1) and have reanalysed eleven of the fifteen samples that were included in our original study. The analysis on a sample from the Pueblo Viejo gold deposit in the Dominican Republic, reported in our previous paper, has been superseded by an extensive study of that deposit, the results of which will be reported elsewhere. The remaining four samples were not remeasured since duplicate analyses agreed within our present measuring error limits. The new results presented here indicate a clear correlation between the lead isotropic composition of a mineral deposit and its crustal environment.

\section{Geologic setting of mineralization in the Carib- bean region}

\subsection{Introduction}

The Caribbean region (Fig. 1) includes four island arc systems: Central America, the Greater 
Antilles, the Lesser Antilles, and the islands north of South America. Although the distribution and types of mineral deposits differ from arc to arc [6] most of this variation is seen in Central America and the Greater Antilles to which we have confined this study. The Greater Antilles developed by interaction between the Americas and Caribbean plates in Mesozoic and early Cenozoic time, whereas Central America interacted with the Cocos plate, at least in Cenozoic time [7].

\subsection{Basement rock}

Northern Central America is underlain by an extensive pre-Mesozoic craton that is divided into two parts by the Polochic-Motagua fault zone that is considered to be the Americas-Caribbean plate boundary [8]. The presence of ophiolites in this zone [9] supports the suggestion from paleomagnetic data $[10,11]$ that northern Central America actually consists of two pre-Mesozoic crustal fragments that are separated approximately by the Polochic-Motagua fault zone. Dengo [12] recognized differences between the pre-Mesozoic rocks on opposite sides of this zone and called the northern part the Maya block and the southern part the Chortis block (Fig. 1).

No such metamorphic basement complex is present in southern Central America or the Greater Antilles. Dengo [13] and del Guidice and Recchi [14] report ophiolite complexes along western Costa Rica and Panama (Fig. 1) and similar rocks are present from eastern Cuba to Puerto Rico in the Greater Antilles [15-18]. Small exposures of phyllitic rocks similar to those in nuclear Central America are found in westernmost Cuba [19].

The approximate extent of the metamorphic craton in northern Central America is shown by the $30-\mathrm{km}$ depth contour to the M-discontinuity [20] as shown in Fig. 1. Throughout southern Central America, the crustal thickness is considerably less than $30 \mathrm{~km}$ except in northern Costa Rica (Fig. 1). No metamorphic core has been identified in this area even though the crust is thicker there. Crustal thickening may be related to the fault zone which forms the southern boundary of the Chortis block, according to Dengo [12]. Thin crust prevails throughout the Greater Antilles ex- cept for a possible metamorphic core beneath western Cuba.

\subsection{Mineral deposits}

All of the Central American mineral deposits included in this study are of Cenozoic or probably Cenozoic age [6]. In northern Central America, deposits in the Maya block and in the PolochicMotagua fault zone, contain lead-zinc, are hosted by Cretaceous and Paleozoic limestones, and show similarities to the Mississippi Valley-type deposits of North America [21]. Deposits south of the fault zone in the Chortis block of northern Central America include: (1) silver-lead-zinc limestone replacement deposits (Mochito, Las Animas, La Vueltosa, Las Minas) in Cretaceous limestone; and (2) silver-gold-lead-zinc veins in Cenozoic volcanic rocks (Monte Cristo, Bonanza, El Rosario).

As noted by Cumming and Kesler [1], lead mineralization and trace lead are less abundant in southern Central America and the Greater Antilles. In southern Central America, the only galenabearing samples available to us are from late veinlets in the large Cerro Colorado porphyry copper deposit and the Boston gold-silver vein deposit in Costa Rica. Both deposits are late Cenozoic in age $[22,23]$. In the Greater Antilles, galena is found in volcanogenic massive sulphide deposits of Jurassic age (Cuba), early Cretaceous age (Haiti) and early Cenozoic age (Jamaica) [6], as well as probable early Cenozoic vein deposits in Puerto Rico [24].

An important aspect of the samples included in this study is the fact that they range in age from Jurassic to Pliocene and are found in host rocks ranging from probably coeval intrusive, volcanic, or sedimentary units, to genetically unrelated sedimentary units ranging from limestone to shale and sandstone. This fact, along with the observation that ore leads commonly exhibit a wider compositional range than related, igneous rock leads $[4$, figs. 1 and 2], suggests that our results may cover essentially the entire range of isotopic compositions to be observed in the Mesozoic and Cenozoic igneous rock and ore leads in this region. 


\section{Results and discussion}

\subsection{Experimental techniques}

The data of our previous paper [1] were essentially of a reconnaissance nature and experimental procedures have improved considerably since that time, hence we have reanalysed most of the original samples in order that they be directly comparable with our new analyses. These new results were obtained over a three-year period and several samples were analysed repeatedly in order to check the long term reproducibility of our measurements.

The measurements were carried out on a Micromass MM30 mass spectrometer using a rhenium filament and the silica gel/phosphoric acid loading technique. The $1-$ to $2-\mu \mathrm{g}$ sample was brought to an operating temperature of $1400^{\circ} \mathrm{C}$ as measured by a disappearing filament optical pyrometer and data were taken after an approximately one-half hour waiting period. Under these experimental conditions the fractionation correction was $0.5 \%$ per mass unit difference. The results of 40 replicate measurements of NBS SRM 981 indicate a measuring precision of about $0.4 \%$ per mass unit difference $(2 \sigma)$, and a correlation coefficient of about 0.75 between pairs of ratios.

Although the experimental procedures varied during the course of this study, we have not rejected measurements except where older measurements have been superseded by more recent values. The data of Table 1 show only the average values. The numbers of replicate analyses are indicated in Table 2. We feel that the above errors are in fact realistic, since when various groupings of data are used to calculate least squares straight lines, the mean squared weighted deviates (MSWD) are always close to one even though errors have been reduced by a factor corresponding to the number of replicates when more than one measurement was averaged for a particular sample.

\subsection{Lead isotopic results}

Our analytical data are shown in Table 1, divided into groups according to their geologic and geographic environment. Most samples were galena, but some pyrite and sphalerite were also analysed and these samples are indicated in the table.

The data of Table 1 can be divided into three main groups (Fig. 2) on the basis of their ${ }^{207} \mathrm{~Pb} /{ }^{204} \mathrm{~Pb}$ and ${ }^{208} \mathrm{~Pb} /{ }^{204} \mathrm{~Pb}$ ratios. These are: (1) the deposits in southern Central America and all deposits in the Greater Antilles except Cuba; (2) all deposits in northern Central America; and (3) the Cuban deposits. We note further that although the data from the Maya and Chortis basement blocks overlap (group 2 above), the Maya block data form an extended linear array, similar in ${ }^{206} \mathrm{~Pb} /{ }^{204} \mathrm{~Pb}$ ratios but enriched in ${ }^{207} \mathrm{~Pb} /{ }^{204} \mathrm{~Pb}$ as compared with group 1 data, whereas the data from the Chortis block form a much shorter and less radiogenic array. In fact, if we exclude samples from the Monte Cristo mine in El Salvador and the sample from the Montenegro deposit in Guatemala, the remaining Chortis block data form a cluster which is scarcely larger than our experimental error.

Adequate explanation of the position of the Monte Cristo analyses is important to a full characterization of the isotopic characteristics of the Chortis block. Unfortunately however, not enough is known about the age and petrology of the volcanic rocks in the Monte Cristo area to determine its relation to other deposits in the Chortis block. In fact, the Monte Cristo deposit and its host volcanic sequence are most similar to the numerous lead-poor, precious metal deposits of southern Central America, which are represented in this study only by the Boston mine (sample 7, Fig. 2). Thus, it is likely that further data are needed on these deposits in order to account adequately for the Monte Cristo analyses. In contrast, all other deposits in the Chortis block for which data are available appear to be part of a single geological group which formed in mid-Cenozoic time, and which has a very restricted range of isotopic compositions.

Comparison of the isotopic data for each deposit with the depth to the M-discontinuity at that locality indicates that there is no simple correlation between isotopic composition and crustal thickness. Note for instance that the Boston mine in Costa Rica has a moderately high ${ }^{206} \mathrm{~Pb} /{ }^{204} \mathrm{~Pb}$ 
TABLE 1

Lead isotopic composition of sulphide minerals from Mesozoic and Cenozoic mineral deposits in the Greater Antilles and Central America. The samples are divided into groups on the basis of their geographic and geologic settings and are listed where possible, in order of decreasing geologic age (sample locations are shown in Fig. 1)

\begin{tabular}{|c|c|c|c|}
\hline Sample No. & ${ }^{206} \mathrm{~Pb} /{ }^{204} \mathrm{~Pb}$ & ${ }^{207} \mathrm{~Pb} /{ }^{204} \mathrm{~Pb}$ & ${ }^{208} \mathrm{~Pb} /{ }^{204} \mathrm{~Pb}$ \\
\hline \multicolumn{4}{|l|}{ Greater Antilles } \\
\hline $\begin{array}{ll}1 & \text { CBA-SL } \\
2 & \text { CBA-CAST } \\
3 & \text { H-K-1 } \\
4 & \text { H-K-2 } \\
5 & \text { PR-72-GA } \\
6 & \text { J-72-HM }\end{array}$ & $\begin{array}{l}18.693 \\
18.714 \\
19.048 \\
19.062 \\
18.877 \\
18.772\end{array}$ & $\begin{array}{l}15.685 \\
15.712 \\
15.621 \\
15.630 \\
15.606 \\
15.593\end{array}$ & $\begin{array}{l}38.828 \\
38.892 \\
38.849 \\
38.859 \\
38.646 \\
38.476\end{array}$ \\
\hline \multicolumn{4}{|c|}{ Southern Central America } \\
\hline $\begin{array}{ll}7 & \text { CR-AB } \\
8 & 78-722 \\
9 & \text { P-CC }\end{array}$ & $\begin{array}{l}18.901 \\
19.054 \\
19.096\end{array}$ & $\begin{array}{l}15.599 \\
15.627 \\
15.605\end{array}$ & $\begin{array}{l}38.710 \\
38.804 \\
38.812\end{array}$ \\
\hline \multicolumn{4}{|c|}{ Northern Central America } \\
\hline $\begin{array}{l}\text { Maya block } \\
10 \text { VL-SJ } \\
11 \text { RB-GA } \\
12 \text { A-27 } \\
13 \text { SD-3 } \\
14 \text { A-143 } \\
15 \text { A-195 } \\
16 \text { TZ-3 } \\
17 \text { A-490 } \\
18 \text { A-467 } \\
19 \text { A-486 }\end{array}$ & $\begin{array}{l}18.939 \\
19.038 \\
18.816 \\
18.831 \\
18.870 \\
18.873 \\
18.737 \\
18.751 \\
18.821 \\
18.870\end{array}$ & $\begin{array}{l}15.668 \\
15.693 \\
15.653 \\
15.668 \\
15.670 \\
15.678 \\
15.642 \\
15.649 \\
15.652 \\
15.659\end{array}$ & $\begin{array}{l}38.867 \\
39.085 \\
38.774 \\
38.790 \\
38.855 \\
38.871 \\
38.685 \\
38.676 \\
38.693 \\
38.789\end{array}$ \\
\hline \multicolumn{4}{|l|}{ Chortis block } \\
\hline 20 PNCO-4-8 & 18.771 & 15.637 & 38.661 \\
\hline 21 MTNG-MTO & 18.801 & 15.654 & 38.714 \\
\hline $22 \mathrm{H}-\mathrm{R}$ & 18.765 & 15.654 & 38.716 \\
\hline $23 \mathrm{H}-\mathrm{LA}$ & 18.766 & 15.639 & 38.678 \\
\hline $24 \mathrm{H}-\mathrm{LV}$ & 18.776 & 15.634 & 38.650 \\
\hline $25 \mathrm{ML}-1225-\mathrm{SJ}$ & 18.777 & 15.649 & 38.703 \\
\hline 26 N-VS-1 & 18.762 & 15.652 & 38.729 \\
\hline $27 \mathrm{~N}-\mathrm{VS}-2$ & 18.748 & 15.637 & 38.663 \\
\hline $28 \mathrm{BLAG}$ & 18.760 & 15.638 & 38.654 \\
\hline 20 LL-I-ES & 18.663 & 15.617 & 38.481 \\
\hline $30 \mathrm{ES}-2-\mathrm{MC}$ & 18.655 & 15.621 & 38.535 \\
\hline
\end{tabular}

ratio with a low ${ }^{207} \mathrm{~Pb} /{ }^{204} \mathrm{~Pb}$ ratio characteristic of the oceanic crust group (Fig. 2), and yet is underlain by crust that is over $40 \mathrm{~km}$ thick (Fig. 1). On the other hand the Monte Cristo deposit comes from an area of relatively thin crust and yet has a higher ${ }^{207} \mathrm{~Pb} /{ }^{204} \mathrm{~Pb}$ ratio coupled with the lowest ${ }^{206} \mathrm{~Pb} /{ }^{204} \mathrm{~Pb}$ ratio of any of the samples in this group. The crust below the Monte Cristo deposit is probably made up in part of Paleozoic rocks. Thus lead isotopic composition may be more closely correlated with crustal type than with crustal thickness alone.

Present models for the plate tectonic evolution of the Central American-Caribbean region [7,25] indicate that there are no suitable DSDP locations which could represent ocean floor material that 
TABLE 2

Notes on the analyses of Table 1 (for samples analysed in duplicate, mean values are given)

\begin{tabular}{lllllll}
\hline $\begin{array}{l}\text { Sample } \\
\text { No. }\end{array}$ & $\begin{array}{l}\text { Number of } \\
\text { duplicates }\end{array}$ & Mineral(s) & Country & District & Deposit & Type \\
\hline Greater Antilles & & & & & \\
1 & 4 & P, G & Cuba & Pinar del Rio & Santa Lucia & massive sulphide \\
2 & 2 & P, G & Cuba & Pinar del Rio & Castillanos & massive sulphide \\
3 & 4 & P, G, S & Haiti & & Camp Coq & massive sulphide \\
4 & 3 & P, G, S & Haiti & & Camp Coq & massive sulphide \\
$5^{*}$ & 1 & G & Puerto Rico & & Hope & massive sulphide \\
$6^{*}$ & I & G & Jamaica & Hope & &
\end{tabular}

Southern Central America

$\begin{array}{lllllll}7 & 4 & \text { G.S } & \begin{array}{l}\text { Costa Rica } \\ \text { Panama }\end{array} & \begin{array}{l}\text { Abangares } \\ \text { Cerro Colorado }\end{array} & \begin{array}{l}\text { Boston } \\ \text { Cerro Colorado }\end{array} & \begin{array}{l}\text { gold-silver vein } \\ \text { porphyry copper deposit } \\ \text { DDH-78, 722 foot depth } \\ \text { peripheral vein at surface }\end{array} \\ 9 & 5 & \text { S } & \text { P. G,S } & \text { Panama } & \text { Cerro Colorado } & \text { Cerro Colorado }\end{array}$

Northern Central America

Maya block
$10^{*}$
$11^{*}$
$12^{*}$
$13^{*}$
$14^{*}$
$15^{*}$
$16^{* *}$
$17^{* *}$
$18^{* *}$
$19^{*}$

1
1
1
1
1
1
1
1
1
1

$\begin{array}{lll}G & \text { Guatemala } & \text { San Miguel } \\ \text { G } & \text { Guatemala } & \text { San Miguel } \\ \text { G } & \text { Guatemala } & \text { Chiantla } \\ \text { G } & \text { Guatemala } & \text { Chiantla } \\ \text { G } & \text { Guatemala } & \text { Chiantla } \\ \text { G } & \text { Guatemala } & \text { Chiantla } \\ \text { G } & \text { Guatemala } & \text { Chiantla } \\ \text { G } & \text { Guatemala } & \text { Coban } \\ \text { G } & \text { Guatemala } & \text { Coban } \\ \text { G } & \text { Guatemala } & \text { Coban }\end{array}$

\begin{tabular}{ll}
\multicolumn{2}{c}{ Chortis hlock } \\
20 & 3 \\
21 & 1 \\
22 & 1 \\
23 & 1 \\
24 & 1 \\
$25 * *$ & 1 \\
26 & 1 \\
27 & 1 \\
28 & 2 \\
$29 *$ & 1 \\
30 & 4
\end{tabular}

$\begin{array}{lll}G, S & \text { Guatemala } & \text { Las Minas } \\ G & \text { Guatemala } & \text { Las Minas } \\ G & \text { Honduras } & \text { San Juancito } \\ G & \text { Honduras } & \text { San Juancito } \\ G & \text { Honduras } & \text { Mochito } \\ G & \text { Honduras } & \text { Mochito } \\ G & \text { Nicaragua } & \text { Bonanza } \\ G & \text { Nicaragua } & \text { Bonanza } \\ G & \text { Nicaragua } & \text { Bonanza } \\ G & \text { El Salvador } & \text { Fonseca } \\ G & \text { El Salvador } & \text { Fonseca }\end{array}$

Villa Linda
Rosario
Santo Domingo
Santo Domingo
Torlon
Torlon
Tziminas
Suquinay
San Joaquin
Caquipec

Peñasco

Montenegro

Las Animas

Las Animas

La Vueltosa

San Jorge

Neptuna

Neptuna

Blag

Monte Cristo

Monte Cristo

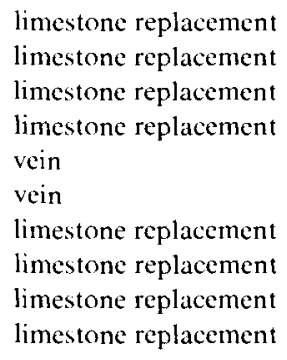

limestone replacement limestone replacement limestone replacement limestone replacement limestone replacement limestone replacement vein

vein

gold-silver vein

silver-gold vein silver-gold vein

$\mathrm{G}=$ galena, $\mathrm{S}=$ sphalerite, $\mathrm{P}=$ pyrite

* Reanalysis of samples previously reported in Cumming and Kesler [1]

** Previously published analysis [1].

might have undergone subduction and partial melting in mid-Cenozoic time to produce the observed isotopic compositions. Thus, it is not possible to use direct mixing models such as that of Church [26] to evaluate the relative importance of such possible lead sources as the mantle, the lower or upper crust, and ocean floor basalt and sediment. It is clear, however, that the majority of data on rock leads from mid-ocean ridge basalts are considerably lower in ${ }^{207} \mathrm{~Pb} /{ }^{204} \mathrm{~Pb}$ and ${ }^{208} \mathrm{~Pb} /$ 


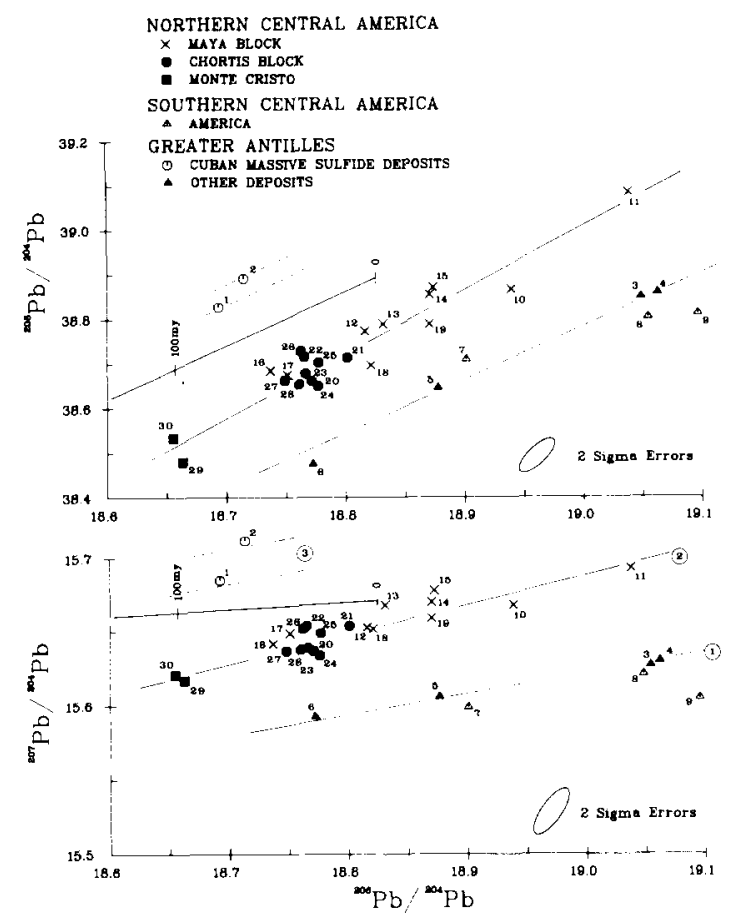

Fig. 2. Isotopic compositions of lead in Central American and Caribbean mineral deposits. Growth curve shown is that of Stacey and Kramers [42]. Lines $I$ and 2 represent best-fit lines for two of the three major divisions of the data $(1=$ southern Central America and the Caribbean region (except Cuba); $2=$ northern Central America). Area 3 represents the Cuban data.

${ }^{204} \mathrm{~Pb}$ than the data presented here (see Tatsumoto [27,fig. 9]). Only our group 1 data from southern Central America and the Greater Antilles overlap the range of compositions for any oceanic rocks and these are the rather atypical data from DSDP Leg 37 [28,29], and from Gough and Reunion islands (see Tatsumoto [27, fig. 11]). By analogy with models adopted for the oceanic island basalts [27], relatively undepleted mantle is the only compositionally acceptable material that could have supplied lead to the Caribbean and southern Central American deposits. Presumably this could have taken place by subduction in the Caribbean region, of mid-ocean ridge basalts derived from such mantle.

Even lead from these oceanic sources is distinctly different from the data from northern
Central America, however, and a source with higher $\mathrm{U} / \mathrm{Pb}$ and $\mathrm{Th} / \mathrm{U}$ ratios must be sought. Although this source could have been either continental material or unusual subcratonic mantle, the small size of the Central American craton and its apparently wide range of Mesozoic and Cenozoic movement [30] make a crustal source seem more likely. In accordance with the generalizations of Zartman [4] regarding the characteristics of lead isotopic analyses from the western United States, it is concluded that the lead forming the linear array in the Maya block was derived from a crustal or mantle source containing a substantial range of $\mathrm{U} / \mathrm{Pb}$ and $\mathrm{Th} / \mathrm{U}$ ratios. In contrast, the Chortis block lead could have been derived from a more homogenized source with a limited range of $\mathrm{U} / \mathrm{Pb}$ and $\mathrm{Th} / \mathrm{U}$ ratios. Alternatively material could have been homogenized at the time of ore formation, but in either case the source of lead is different for the Chortis and Maya blocks.

The Cuban lead exhibits extreme ${ }^{207} \mathrm{~Pb}$ enrichment, possibly reflecting a crustal source for the Jurassic sediments that host them [19, p. 39]. It should be noted that although the two Cuban deposits appear to be the same within experimental error, the duplicate measurements are always clearly distinct from one another; that is, the ratios for sample 2 were always higher than the ratios for sample 1 . We are thus confident that the two deposits differ in composition from each other and thus the isotope ratios reflect real differences in the source of these two leads. This, coupled with the extremely high values of ${ }^{207} \mathrm{~Pb} /{ }^{204} \mathrm{~Pb}$, suggests an enriched and variable crustal source which must have been differentiated from more normal crust at an early age in order to produce the observed spread in the ${ }^{207} \mathrm{~Pb} /{ }^{204} \mathrm{~Pb}$ ratios.

\subsection{Straight line fitting and model age calculations}

We have calculated least squares straight lines [31] for the various data groups (Fig. 2) as indicated above, and used these slopes to determine possible ages of source rocks assuming a two-stage model. Since ages of formation of the various ore bodies range from Jurassic to Pliocene, this is clearly an oversimplification, but the results will not be critically dependent on this approximation. 
For calculation purposes we have used a value for $t_{2}$ of $30 \mathrm{~m} . \mathrm{y}$. (mid-Cenozoic) in the two-stage anomalous lead equation:

$R=\frac{\exp \left(\lambda^{\prime} t_{1}\right)-\exp \left(\lambda^{\prime} t_{2}\right)}{\alpha\left[\exp \left(\lambda t_{1}\right)-\exp \left(\lambda t_{2}\right)\right]}$

where $R$ is the slope of the line and the decay constants and uranium isotope ratios are as recommended by Steiger and Jäger [32].

The eleven ratios for samples from the Chortis block yield a line of slope $R=0.186 \pm 0.030$ and MSWD $=1.33$. From the Maya block, ten samples fit a line of slope $R=0.146 \pm 0.029$ and MSWD $=$ 0.98 . These slopes yield ages of $2680 \pm 250$ m.y. and $2280 \pm 310$ m.y. (1o) respectively, with relatively large errors due to the short lines. The combined data sets from the Maya and Chortis blocks form a line of slope $R=0.195 \pm 0.015$ with $\mathrm{MSWD}=1.31$. Although the error for this line has decreased considerably, the age $\left(t_{1}=2780 \pm 120\right.$ m.y.) and slope are even greater than those of the individual groups. The ages indicated for the source of the Central American ores from these calculations are clearly much greater than the oldest radiometric dates in the area. Gomberg et al. [33] obtained ages of 1000 m.y. on zircons from the metamorphic core of the Maya block. Rocks of great age are also lacking in southern Mexico [34] and northwestern South America [35], but older rocks are present in northeastern South America [36].

The data from southern Central America and the Greater Antilles also form a colinear group, if we exclude the late vein sample (P-CC) from Cerro Colorado. We obtain a slope of $R=0.143 \pm 0.016$ with MSWD $=1.49$. This yields an apparent age from the source rock for these ores of $2250 \pm 180$ m.y. $(1 \sigma)$, very similar to the Maya block data discussed above. Including sample P-CC in the calculation reduces the slope to $R=0.032 \pm 0.017$ but with MSWD $=19.4$, thus indicating that this sample does not fit the pattern of the remaining analyses of this group. This discrepancy is not due to experimental error. All measurements on sample $\mathrm{P}-\mathrm{CC}$ had higher ${ }^{206} \mathrm{~Pb} /{ }^{204} \mathrm{~Pb}$ and lower ${ }^{207} \mathrm{~Pb} /{ }^{204} \mathrm{~Pb}$ ratios than those measured for sample 78-722 from within the deposit proper.

\section{Relation of Caribbean and Mexican lead iso- topic data and source of the lead}

Inasmuch as the Cenozoic tectonic processes that generated the Central American mineralization extended northward into Mexico and, in fact, were most extensive there, it is reasonable to compare the new Central American analyses to our recently published data from Mexico [37]. As can be seen in Fig. 3, there is considerable overlap between data from Mexico and northern Central America, although the Central American Maya block analyses extend to higher ratios and the Mexican analyses extend to lower ratios. An important characteristic of the isotopic data from most of the larger deposits in Mexico was their uniformity of isotopic composition. Analyses from important mineral districts such as Taxco, Fresnillo, and Parral (Fig. 3) formed clusters similar to those observed for the Chortis block analyses. As can be seen in Fig. 3, the composition of these Mexican clusters is very similar to that of the Chortis block. Furthermore, the stippled area surrounding these clusters includes almost all of the mineral deposits in northern Mexico. It is likely, therefore, that the same process or crustal influence prevailed during formation of the lead in most of the Mexican deposits and in those of the Chortis block. Those deposits with analyses falling outside the stippled zone come largely from southern or northernmost Mexico (Fig. 4) where it is possible that uranium-depleted, lower crustal material was a source of the lead. Limited data available to us (analyses 1, 2, 3, 4, 5, 10 in fig. 3 of Cumming et al. [37]), as well as the conclusions of Ewing [38] regarding lead isotopic data from New Mexico, suggest that the data from northernmost Mexico fall in a linear array, indicating a $t_{1}$ of about 1.5 b.y. for a $t_{2}$ of mid-Cenozoic age, and consistent with the known age of the basement in that area. We are thus led to conclude that if Mexican lead ores appear to reflect the age of underlying basement rocks, then the Central American lead data could also indicate the ages of the source rocks, although these rocks have not yet been identified in the field. It is interesting to speculate that if the lead isotope ratio patterns for these ores yield information about ages of underly- 

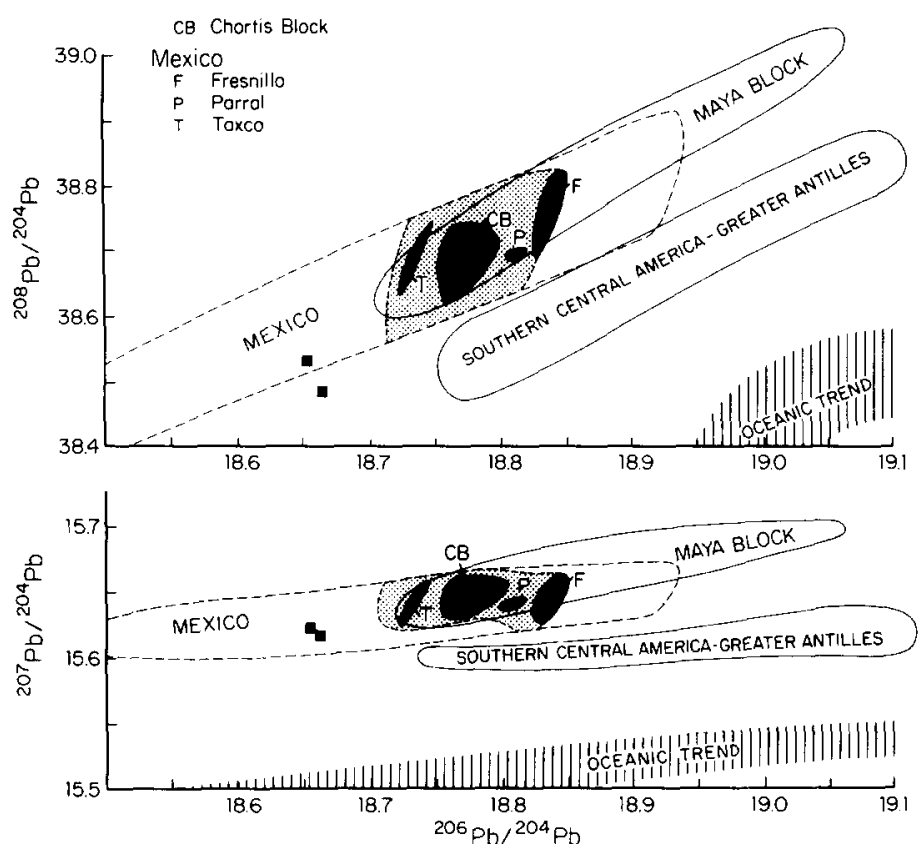

Fig. 3. Compositional fields for lead isotopic data from Mexico, Central America and the Caribbean region compared to lead in typical oceanic basalts [27]. Specific clusters in the Mexican data are located in Fig. 4.

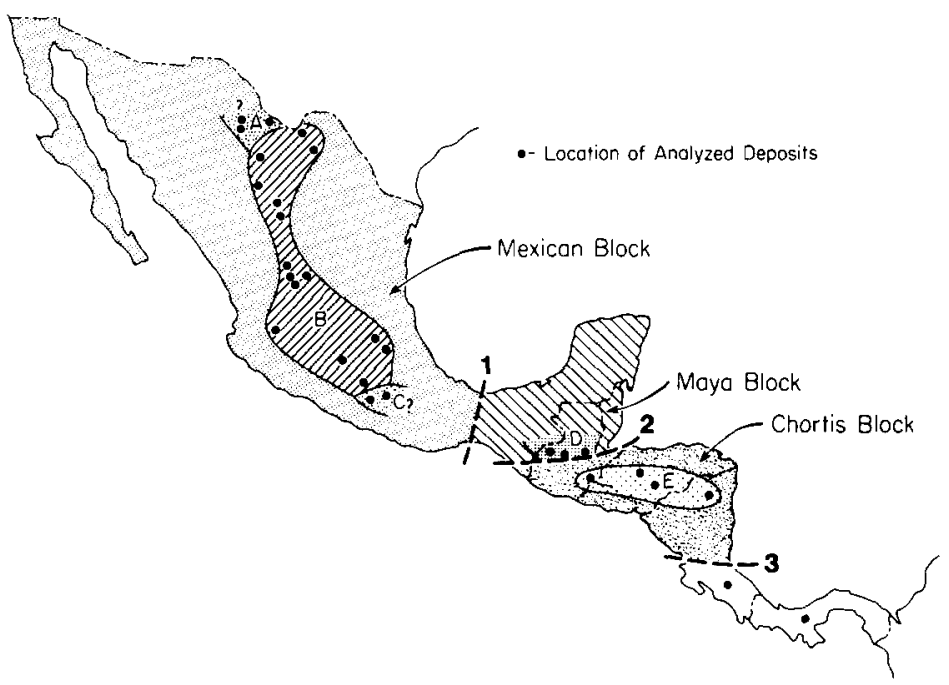

Fig. 4. Distribution of deposits analysed in this study, as well as most of those analysed by Cumming et al. [37] from Mexico. The heavy dashed lines $(1,2,3)$ separate crustal segments thought to have had separate plate tectonic histories in Mesozoic and Cenozoic time [30]. Areas $A$ and $C$ in Mexico contain deposits with lead isotopic compositions distinct from area $B$ as noted in the text. Area $E$ in Central America (the Chortis block) is isotopically similar to area $B$ and could be a fragment of that terrain. 
ing rocks, then perhaps similar patterns for oceanic rocks yield similar information about ages of source rocks, and do not necessarily result from simple mixing of two end members without time significance. This interpretation would be consistent with Chase's [39] view that oceanic basalts can best explained in terms of two-stage models.

In addition to providing insights into the source of lead in the mineralization, our observations appear to be useful to characterize crustal frag. ments in the Mexican-Central American region. For instance, geologic and paleomagnetic data suggest that the region can be divided into at least 4 crustal fragments, including the Maya and Chortis blocks [30]. Considerable uncertainty persists over the provenance of the Maya and Chortis blocks, with the most commonly suggested possibility being detachment from western Mexico and transport southward [40,41]. The similarity of lead isotopic data from the Chortis and the Mexican blocks, lends credence to this possibility.

\section{Acknowledgements}

Laboratory work for this report was supported by NSERC, and field work was supported by several private mining companies. Samples were also contributed by D.J.T. Carson and R.H. Pemberton (Cuba), Charles L. Dahl (Haiti), George L. Riley (Costa Rica), M. Seaward (Honduras and Nicaragua) and D.M. Wyslousil (Guatemala).

\section{References}

1 G.L. Cumming and S.E. Kesler, Source of lead in Central American and Caribbean mineralization. Earth Planet. Sci. Lett. 31 (1976) 262.

2 B.R. Doe and R.E. Zartman, Plumbotectonics, I. The Phanerozoic, in: Geochemistry of Hydrothermal Ore Deposits, H.L. Barnes, ed. (John Wiley and Sons, New York, N.Y., 1979) 2nd ed

3 J.S. Stacey, R.E. Zartman and I.T. Nkomo, A lead isotope study of galenas and selected feldspars from mining districts in Utah. Econ. Geol. 63 (1968) 796.

4 R.E. Zartman, Lead isotope provinces in the Cordillera of the Western United States and their geologic significance, Econ. Geol. 69 (1974) 792.

5 J.S. Stacey and R.E. Zartman, A lead and strontium iso- topic study of igneous rocks and ores from the Gold Hill mining district, Utah, Utah Geol. 5,1 (1979) 1.

6 S.E. Kesler, Metallogenesis of the Caribbean region, J. Geol. Soc. London 135 (1978) 429.

7 J.R. Ladd, Relative motion of South America with respect to North America and Caribbean tectonics, Geol Soc. Am: Bull. 87 (1976) 869.

8 P. Molnar and L.R. Sykes, Tectonics of the Caribbean and Middle America regions from local mechanisms and seismicity, Geol. Soc. Am. Bull. 80 (1969) 1639

9 H.H. Wilson, Cretaceous sedimentation and orogeny in Central America, Am. Assoc. Pet. Geol. Bull. 58 (1974) 1348.

10 W.A. Gose and D.K. Swartz, Paleomagnetic results from Cretaceous sediments in Honduras: tectonic implications, Geology 5 (1977) 505 (see also discussions in Geology 6 (1978) 440).

11 W.D. MacDonald, The Honduras paleomagnetic clock and the Tertiary evolution of the Caribbean, EOS, Trans. Am. Geophys. Union 58, 6 (1977) 376.

$12 \mathrm{G}$. Dengo, Problems of tectonic relations between Central America and the Caribbean, G.C.A.G.S. Trans. 19 (1969) 311

13 G. Dengo, Tectonic igneous sequence in Costa Rica, Buddington Vol., Geol. Soc. Am. (1962) 133

14 D. del Guidice and G. Recchi, Geologia del area del proyecto minero de Azuero, Proyecto Minero Panama, Fas I, Naciones Unidas, Panama (1969) 48 p.

15 P.H. Mattson, Middle Cretaceous nappe structures in Puerto Rican ophiolites and their relation to the tectonic history of the Greater Antilles, Geol. Soc. Am. Bull 84 (1973) 1.

16 P.H. Mattson, Cuba, in: Mesozoic and Cenozoic Orogenic Belts, A.M. Spencer, ed., Spec. Publ. Geol. Soc. London 4 (1973) 625 .

17 D.F. Cox, R.F. Marvin, J.W. M'Gonigle, D.H. MeIntyre and C.L. Rogers, Potassium argon geochronology of some metamorphic, igneous and hydrothermal events in Puerto Rico and Virgin Islands, U.S. Geol. Surv. J. Res. 5 (1978) 689.

18 S.E. Kesler, J.F. Sutter, L.M. Jones and R.L. Walker, Early Cretaceous basement rocks in Hispanola, Geology 5 (1977) 245.

19 K.M. Khudoley and A.A. Meyerhoff, Paleogeography and geological history of Greater Antilles, Geol. Soc. Am. Mem. 129 (1971) $199 \mathrm{pp}$.

20 J.E. Case, Crustal setting of mafic and ultramafic rocks and associated ore deposits of the Caribbean region. U.S. Geol Surv. Open-file Rep. 80-3041 (1980) 95 pp.

21 S.E. Kesler and R. Ascarrunz-K, Lead-zinc mineralization in carbonate rocks, central Guatemala, Econ. Geol. 68 (1973) 1263

22 S.E. Kesler, J.F. Sutter and M.J. Issigonis, Evolution of porphyry copper mineralization in an oceanic island arc, Panama, Econ. Geol. 72 (1977) 1142.

23 R. Weyl, Geology of Central America (Gebruder Borntraeger, Berlin, 1970) 2nd ed., 371 pp.

24 H.L. Berryhill, Geology of the Ciales quadrangle, Puerto Rico, U.S. Geol. Surv. Bull. 1184 (1965) 116 pp 
25 R. Hey, Tectonic evolution of the Cocos-Nazca spreading Center, Geol. Soc. Am. Bull, 88 (1977) 1404.

26 S.E. Church. The Cascade Mountains revisited: a reevaluation in light of new lead isotopic data, Earth Planet. Sci. Lett. 29 (1976) 175.

$27 \mathrm{M}$. Tatsumoto, Isotopic composition of lead in oceanic basalt and its implication to mantle evolution, Earth Planet. Sci. Lett. 38 (1978) 63.

28 G.L. Cumming, Lead isotope ratios in Deep Sea Drilling Project Leg 37 basalts, Earth Planet. Sci. Lett. 31 (1976) 1979.

29 M. Yamaguchi, R.D. Russell and W.F. Slawson, Concentration and composition of lead in Deep Sea Drilling Project Leg 37 cores, Can. J. Earth Sci. 14 (1977) 785.

30 W.A. Gose, G.R. Scott and D.K. Swartz, The aggregation of Mesoamerica: paleomagnetic evidence, in: The Origin of the Gulf of Mexico and the Early Opening of the Central North Atlantic Ocean, R.H. Pilger, ed., Louisiana State Univ., Dep. Geol., Publ. (1980) 51.

31 G.L. Cumming, J.S. Rollet, E.J.C. Rossotti and R.F. Whewell, Statistical methods for the computation of stability constants, I. Straight-line fitting of points with correlated errors, J. Chem. Soc. Dalton Trans. (1972) 2652.

32 R.H. Steiger and E. Jäger, Subcommission on Geochronology: convention on the use of decay constants in geochronology and cosmochronology, in: Contributions to the Geologic Time Scale, Am. Assoc. Pet. Geol. Stud. Geol. 6 (1978) 67.
33 D.N. Gomberg, P.D. Banks and A.R. McBirney, Guatemala: preliminary zircon ages from the central cordillera, Science 162 (1968) 121.

34 G. Salas, Carta y provincias metalogeneticas de la Republica Mexicana, Cons. Rec. Miner. Publ. 2 IE (1975) 242 pp.

35 C.M. Tschanz, R.F. Marvin, B.M. Cruz, H.H. Mehnert and G.T. Cebula, Geologic evolution of the Sierra Nevada de Santa Marta, northeastern Columbia, Geol. Soc. Am. Bull. 85 (1974) 273.

36 C. Martin-Bellizzia, Edades isotopicas de rocas Venezolanas, Venzuela Bol. Geol. 10, 19 (1968) 356.

37 G.L. Cumming, S.E. Kesler and D. Krstic, Isotopic composition of lead in Mexican mineral deposits, Econ. Geol. 74 (1979) 1395.

38 T.E. Ewing, Lead isotope data from mineral deposits of southern New Mexico: a reinterpretation, Econ. Geol. 74 (1979) 678.

39 C.G. Chase, Oceanic island $\mathrm{Pb}$ : two-stage histories and mantle evolution, Earth Planet. Sci. Lett. 52 (1981) 277.

40 D.E. Karig, R.K. Cardwell, G.F. Moore and D.G. Moore, Late Cenozoic subduction and continental margin truncation along the northern Middle America Trench, Geol. Soc. Am. Bull. 89 (1978) 265

4 I B.T. Malfait and M.G. Dinkelman, Circum-Caribbean tectonic and igneous activity and the evolution of the Caribbean plate, Geol. Soc. Am. Bull. 83 (1972) 251.

42 J.S. Stacey and J.D. Kramers, Approximation of a terrestrial lead isotope evolution by a two-stage model, Earth Planet. Sci. Lett. 26 (1975) 207. 